\title{
Design and In Vitro Characterization of Orally Disintegrating Modified Release Tablets of Naproxen Sodium
}

\section{Naproksen Sodyumun Ağızda Dağılan Değiştirilmiş Salım Tabletlerinin Tasarımı ve In Vitro Karakterizasyonu}

\author{
(D) Nadeem Irfan BUKHARI ${ }^{1}$, (D) Faisal MAHMOOD ${ }^{1}$ \\ 1 University College of Pharmacy, University of the Punjab, Lahore, Pakistan \\ 2Department of Pharmaceutics, Faculty of Pharmaceutical Sciences, GC University Faisalabad, Pakistan \\ 3Faculty of Pharmacy, Bahauddin Zakariya University, Multan, Pakistan
}

(D) Amjad HUSSAIN ${ }^{*}$, (D) Maham MISBAH ${ }^{1}$, (D) Nasir ABBAS1, (D) Muhammad IRFAN², (D) Muhammad Sohail ARSHAD ${ }^{3}$, (D) Rahat SHAMIM1,

\begin{abstract}
Objectives: The aim of this study was to prepare orally disintegrating, slow release tablets of naproxen sodium for prompt onset and sustained action required in many types of acute pain.

Materials and Methods: Tablet formulations containing varying concentrations of croscarmellose sodium (a superdisintegrant) and Soluplus ${ }^{\circledR}$ (as release modifier) were prepared by wet granulation method using a single punch tablet machine. The prepared granules were evaluated for their bulk properties and the tablets were evaluated for hardness, disintegration time, and drug release profiles.

Results: The results showed that the granules so prepared have good flow and compressional properties. A disintegration time of tablets $<30$ s was achieved by selecting an optimum concentration of croscarmellose sodium. The drug release from the tablets was sustained for $2 \mathrm{~h}$ by incorporating a suitable amount of Soluplus ${ }^{\circledR}$.

Conclusion: This study examined the use of Soluplus ${ }^{\circledR}$ (a novel solubilizer) for the first time as a release modifier of API from tablets.
\end{abstract}

Key words: Orally disintegrating tablets, modified release tablets, naproxen sodium, Soluplus ${ }^{\circledR}$

öz

Amaç: Bu çalışmanın amacı, birçok akut ağrı tipinde gerekli olan hızlı ve sürekli etki için ağızda dağılan, yavaş salımlı naproksen sodyum tabletlerinin hazırlanmasıdır.

Gereç ve Yöntemler: Farklı konsantrasyonlarda kroskarmeloz sodyum (bir süper dağıtıcı) ve Soluplus ${ }^{\circledR}$ (salım değiştirici olarak) içeren tablet formülasyonları, tek zımbalı tablet makinesi kullanılarak ıslak granülasyon yöntemi ile hazırlandı. Hazırlanan granüller, yığın özellikleri açısından değerlendirildi ve tabletler, sertlik, parçalanma süresi ve ilaç salım profilleri açısından değerlendirildi.

Bulgular: Bu șekilde hazırlanan granüllerin iyi akış ve sıkıștırma özelliklerine sahip olduğu tespit edildi. Optimum kroskarmeloz sodyum konsantrasyonu seçilerek 30 saniyelik bir tablet parçalanma süresine ulaşıldı. Tabletlerden ilaç salımı, uygun miktarda Soluplus ${ }^{\circledR}$ eklenerek 2 saat süreyle sürdürüldü.

Sonuç: Bu çalışmada, Soluplus ${ }^{\circledR \prime}$ un (yeni bir çözücü) ilk kez tabletlerden API'nın salım değiștiricisi olarak kullanımını araştırıldı. Anahtar kelimeler: Ağızda dağılan tabletler, değiștirilmiş salım tabletleri, naproksen sodyum, Soluplus ${ }^{\circledR}$ 


\section{INTRODUCTION}

The design and manufacture of solid oral dosage forms (tablets and capsules) are widespread as the oral route is preferred by both healthcare professionals ${ }^{1}$ and patients. ${ }^{2,3}$ The main advantages include: easy for self-administration, ${ }^{4}$ cost-effective $^{5}$ highly stable dosage forms, and dispensing in more ready to administer forms. ${ }^{4}$ On the other hand, some problems are also associated with the use of solid oral dosage forms in conventional or immediate release tablets such as the frequent administration and small residence time of the drug in the plasma due to its short half-life, leading to fluctuation in plasma level and noncompliance by the patients due to frequent administration. The development of modified release tablets is an advancement in the design of tablets that overcomes these problems associated with the conventional tablet design and promotes a constant plasma level and improves patient compliance. ${ }^{6,7}$

Although these modified release tablets overcome several problems associated with conventional tablets, they also possess the drawback of being larger than the immediate release tablets of the same drug. This makes them difficult to swallow, particularly for geriatric patients and those suffering from dysphagia, a condition marked by difficulty in swallowing, which is reported in about 35\% of the general population, $30-$ $40 \%$ of elderly in-patients, and $18-22 \%$ of all people in longterm care facilities. This difficulty reduces patient compliance but can be overcome ${ }^{4}$ by producing orally disintegrating tablets (ODTs). An ODT is one that disintegrates into small granules within 30 s of its placement in the oral cavity. ${ }^{8}$ The small granules produced thereby can easily be swallowed as compared to swallowing the whole tablet. ${ }^{9}$ ODTs are also advantageous for travelers, who can take their medicine without the requirement of water. According to a survey, the majority of patients prefer to have an ODT than conventional forms of tablets. ${ }^{8}$ Therefore, an ODT improves patient compliance.

Recently, researchers have become increasingly interested in developing modified release ODTs that combine the abovementioned benefits of both modified release dosage forms and ODTs. ${ }^{10,11}$

Naproxen sodium is the drug of choice for rheumatoid arthritisassociated joint pain and early morning stiffness. Hence, a modified release preparation of naproxen sodium would be useful for maintaining a sustained level of naproxen sodium at the required time. The half-life of naproxen sodium is $14 \mathrm{~h}$; therefore, its effect is long lasting but repeated administration of an immediate release formulation will lead to spikes in plasma concentration of the drug, thus making the pain-relieving effect erratic and remitting, as well as leading to gastro-intestinal irritation due to the high drug concentration at one time. In order to maintain a sustained level of drug plasma concentration with minimum variations, a sustained release formulation is required that will lead to sustained pain relief action and a more optimal therapeutic response with minimal side effects. Moreover, due to the high protein binding of naproxen sodium (99.7\%), it may be more efficient to deliver this drug as a sustained release dosage form. ${ }^{12}$

Additionally, an orally disintegrating formulation with sustained release characteristics will certainly benefit the patient with quick onset of action. Naproxen sodium has been declared an ideal candidate for development into an ODT. ${ }^{13}$ In the present study, an orally disintegrating modified release matrix tablet of naproxen sodium was prepared by incorporating Soluplus ${ }^{\circledR}$, a novel amphiphilic graft copolymer. In parallel, the potential of Soluplus ${ }^{\circledR}$ as a tablet binder and as a release modifier for water-soluble drug was investigated.

\section{MATERIALS AND METHODS}

Naproxen sodium was obtained as a gift sample from Pacific Pharmaceuticals Pvt. Ltd, Lahore, Pakistan; Soluplus ${ }^{\circledR}$ was purchased from BASF, UK; and croscarmellose sodium, starch, and all other excipients (pharmaceutical grade) were purchased from the local market of Lahore, Pakistan, and were used as received.

\section{Preparation of ODTs}

The design of the tablet formulations was accomplished in two phases. The target of the first phase was to achieve fast disintegration of tablets, i.e. within $30 \mathrm{~s}$. Eight trial tablet formulations (F1-F8) were prepared (see Table 1) by wet granulation method by varying the concentration (2-20\%) and distribution (extragranular/intragranular) of superdisintegrant, i.e. croscarmellose sodium. For this purpose, a dry mixture of naproxen sodium (API), starch (disintegrant), and lactose monohydrate (diluent) was prepared in a tumbler mixture. This mixture was then moistened by using $2.5 \%$ Soluplus ${ }^{\circledR}$ solution

\section{Table 1. Composition of trial formulations F1-F8}

\begin{tabular}{|c|c|c|c|c|c|c|}
\hline Formulation & Naproxen sodium (mg) & CSS (\% w/w) Extra-gran & CSS (mg) Intra-gran & Starch (mg) & Magnesium stearate (mg) & Lactose Qs (mg) \\
\hline F1 & 200 & 10 & - & 10 & 3 & 400 \\
\hline $\mathrm{F} 2$ & 200 & 20 & - & 10 & 3 & 400 \\
\hline F4 & 200 & 40 & - & 10 & 3 & 400 \\
\hline F5 & 200 & 5 & 5 & 10 & 3 & 400 \\
\hline $\mathrm{F} 7$ & 200 & 15 & 15 & 10 & 3 & 400 \\
\hline F8 & 200 & 20 & 20 & 10 & 3 & 400 \\
\hline
\end{tabular}


as binder and the wet mass was screened through sieve 8 to produce granules. The granules were then dried in a hot air oven for $24 \mathrm{~h}$. Croscarmellose sodium as superdisintegrant ${ }^{14}$ and magnesium stearate (1.5\%) as lubricant were mixed with these granules and the mixtures were compressed in a single punch tablet machine (locally manufactured, Lahore, Pakistan). In the next phase, sustaining the release of naproxen sodium was the target. For this purpose, eight test formulations (F9F16) were prepared having same composition of API, diluent, superdisintegrant (optimum concentration), and binder, except for the incorporation of varying concentrations of Soluplus ${ }^{\circledR}$ ( $5 \%$ to $50 \% \mathrm{w} / \mathrm{w}$ of drug), as release modifier. A control tablet formulation of naproxen sodium (FO) was also prepared containing superdisintegrant but no release modifier for comparison purposes.

\section{Characterization of granules}

In order to determine the compaction and flowability, bulk and tapped densities and angle of repose of prepared granules of each formulation were measured. Porosity, compressibility index, and Hausner's ratio were calculated using the tapped and bulk densities data.

\section{Characterization of tablets}

Tablets of each formulation were tested for their hardness, disintegration time, and drug release characteristics. Tablet hardness/crushing strength was measured in triplicate by applying a force until the tablet was crushed using a digital hardness tester (Curio/2020+, Pakistan) and the average value was reported for each formulation.

The disintegration of each formulation was tested by using the method described in the literature. ${ }^{11}$ For this purpose, a tablet from each formulation was placed in a petri dish containing distilled water maintained at $\sim 37^{\circ} \mathrm{C}$. The time taken by the tablet to disintegrate completely was recorded by stopwatch. The measurements were performed in triplicate and the average disintegration time for each test formulation was reported. The disintegration pattern of tablets was also photographed by stereo-zoom microscope (model SZ2-ILST/Olympus Corporation, Japan).

\section{In vitro drug release studies}

In vitro drug release of naproxen sodium from the test formulations was carried out in a USP type II (paddle) dissolution apparatus (Curio, Pakistan). Phosphate buffer $(\mathrm{pH}$ 7.4) was selected as dissolution medium and $900 \mathrm{~mL}$ of this was added to each flask of the test apparatus and the temperature of the medium was maintained at $37 \pm 0.5^{\circ} \mathrm{C}$. One tablet was placed in each dissolution flask and the paddle was rotated at $50 \mathrm{rpm}$. Aliquots of $5 \mathrm{~mL}$ were withdrawn at various intervals and replaced with equal amounts of fresh dissolution medium to maintain the sink conditions. The samples were diluted adequately and analyzed spectrophotometrically for their naproxen sodium content.

For the purpose of the ultraviolet assay, the absorbance of each sample was recorded in triplicate at $271 \mathrm{~nm}$ (i.e. $\lambda_{\text {max }}$ of naproxen sodium determined in this study). From the average value of this absorbance, the corresponding value of concentration was calculated from the calibration curve. The calibration curve (absorbance vs concentration) was plotted by measuring the absorbance of stock solution and its dilutions. The plot was linear between the concentration range of $10 \mu \mathrm{g} / \mathrm{mL}$ and 50 $\mu \mathrm{g} / \mathrm{mL}$ naproxen sodium with the coefficient of regression approaching unity, i.e. 0.998. The values of the intercept and gradient were 0.0093 and 0.0131 , respectively.

\section{Statistical analysis}

The drug release data are presented as mean \pm standard deviation and were analyzed by One-Way ANOVA. The statistical differences were set at $p<0.05$.

\section{RESULTS AND DISCUSSION}

\section{Bulk properties of granules}

The values of bulk and tapped density of the granules of all formulations are summarized in Table 2. The values of bulk density ranged between 0.234 and $0.341 \mathrm{~g} / \mathrm{mL}$ and of tapped density between 0.250 and $0.357 \mathrm{~g} / \mathrm{mL}$. From these values the respective Carr's index and Hausner's ratio were obtained.

The values of Carr's index were in the range of $3.23 \%$ to $12.5 \%$, whereas the values of Hausner's ratio were between 1.03 and 1.13, which shows excellent flow properties of all formulations (F1-F16) except for one (F3), which showed good flow properties. Carr's index corresponds to powder bridge strength and stability, while Hausner's ratio depicts interparticulate friction. Therefore, given the low values of both these parameters for all formulations, one can expect good die fill and proper compressible tablets from all formulations. ${ }^{15}$

\section{Hardness of prepared tablets}

The tablet hardness of trial formulations F1-F4 was between 2.9 and $3.3 \mathrm{~kg} / \mathrm{cm}^{2}$ (Table 3). However, incorporation of disintegrant into the granules (formulation F5-F8) increased the overall hardness of the tablets (average hardness $\sim 3.4 \mathrm{~kg} / \mathrm{cm}^{2}$ ). The test formulations F9-F16 also showed hardness of $\sim 3.4 \mathrm{~kg} / \mathrm{cm}^{2}$. These hardness values are lower than those of regular tablets, i.e. $4-6 \mathrm{~kg} /\left(\mathrm{cm}^{2}\right){ }^{16}$ however, they are still sufficient to tolerate any stress during manufacturing and processing. ${ }^{17}$

\section{Disintegration time}

The results show that the disintegration time was inversely proportional to the concentration of superdisintegrant as it decreased from 68 min for $\mathrm{F} 1$ containing $5 \%$ of disintegrant to 7.5 min for F4 containing $20 \%$ of it. The mode of addition of disintegrant also influences the disintegration time. The formulations containing only extragranular disintegrants (F1-F4) showed disintegration times $>35$ min. However, in formulations where the disintegrant was also added intragranularly (F5F8), the disintegration time was much lower, i.e. between 0.45 and 7.5 min (Table 3). Out of these formulations, F6 showed rapid disintegration, i.e. $0.45 \mathrm{~min}$ ( $27.3 \mathrm{~s}$ ), satisfying the limits set for ODTs. This indicated that not only the addition of superdisintegrant but also the mode of addition (intragranular or extragranular or both) affects the disintegration time. ${ }^{18}$ The 
Table 2. Values of bulk density, tapped density, Hausner's ratio, porosity, and Carr's index and corresponding flow properties of granules of different formulations

\begin{tabular}{|c|c|c|c|c|c|c|c|c|}
\hline Formulation & Bulk volume & $\begin{array}{l}\text { Tapped } \\
\text { volume }\end{array}$ & $\begin{array}{l}\text { Bulk density } \\
(\mathrm{g} / \mathrm{mL})\end{array}$ & $\begin{array}{l}\text { Tapped } \\
\text { density } \\
(\mathrm{g} / \mathrm{mL})\end{array}$ & Carr's index & $\begin{array}{l}\text { Hausner } \\
\text { Ratio }\end{array}$ & Porosity & Flow properties \\
\hline F1 & 5.2 & 5.0 & 0.288 & 0.300 & 4.0 & 1.04 & 3.8 & Excellent \\
\hline $\mathrm{F} 2$ & 5.4 & 5.2 & 0.278 & 0.288 & 3.85 & 1.04 & 3.7 & Excellent \\
\hline F3 & 5.4 & 4.8 & 0.278 & 0.313 & 12.5 & 1.13 & 11.11 & Good \\
\hline F6 & 6.4 & 6.2 & 0.234 & 0.242 & 3.23 & 1.03 & 3.12 & Excellent \\
\hline F7 & 6.2 & 5.6 & 0.241 & 0.268 & 10.7 & 1.11 & 9.6 & Excellent \\
\hline F8 & 6.4 & 5.8 & 0.234 & 0.259 & 10.3 & 1.1 & 9.37 & Excellent \\
\hline F9 & 4.8 & 4.6 & 0.313 & 0.326 & 4.3 & 1.04 & 4.16 & Excellent \\
\hline $\mathrm{F} 12$ & 5.4 & 5.0 & 0.277 & 0.3 & 8 & 1.08 & 7.40 & Excellent \\
\hline F13 & 6.2 & 6.0 & 0.242 & 0.25 & 3.3 & 1.03 & 3.22 & Excellent \\
\hline F14 & 6.4 & 6.0 & 0.234 & 0.25 & 6.7 & 1.06 & 6.25 & Excellent \\
\hline $\mathrm{F} 15$ & 6.0 & 5.4 & 0.25 & 0.278 & 11.1 & 1.11 & 10 & Excellent \\
\hline F16 & 6.0 & 5.6 & 0.25 & 0.268 & 7.1 & 1.07 & 6.66 & Excellent \\
\hline
\end{tabular}

Table 3. Values of hardness and disintegration of trial and test tablet formulations

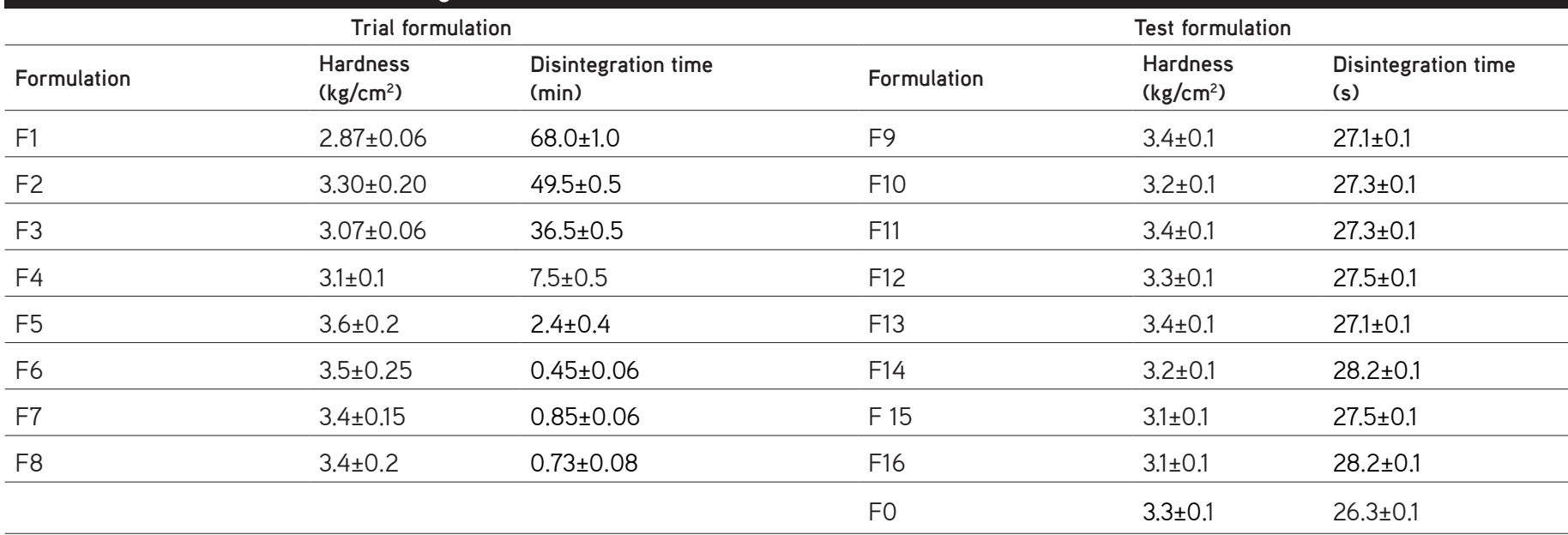

min: Minute

formulation F6 had the fastest dissolution rate as it contained both intra- and extragranular disintegrant and the optimum concentration of superdisintegrants was $10 \%$ each.

The disintegration time of all orally disintegrating test formulations (F9-F16) and blank formulation F0 was almost the same as that of the trial formulations, i.e. $<30 \mathrm{~s}$, as shown in Table 3. This indicates that the different concentrations of Soluplus ${ }^{\circledR}$ have no influence on disintegration time, probably due to its highly water soluble nature. ${ }^{19}$

The rapid disintegration of tablets can be attributed to the wicking and swelling capability of starch and croscarmellose sodium. ${ }^{20}$ This was witnessed in microscopic images of tablets taken during the disintegration test. Figure 1 shows that the tablets were swollen at $15 \mathrm{~s}$ as the water was taken up by the disintegrants, which ultimately led to erosion of the tablets after $20 \mathrm{~s}$.

\section{In vitro drug release}

The release profiles of naproxen sodium from test formulations F9-F16 are shown in Figure 2. It is evident that in the first 10 min the drug release was almost complete (100\%) from F0 and F9, while it was $95 \%$ from F10, 90\% from F11, 90\% from F12, 


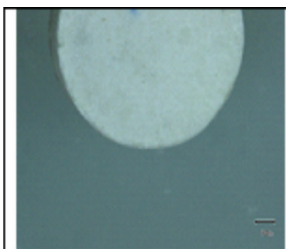

Os

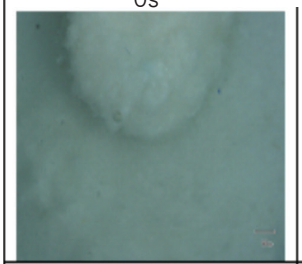

$15 s$

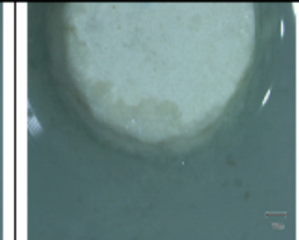

$5 s$

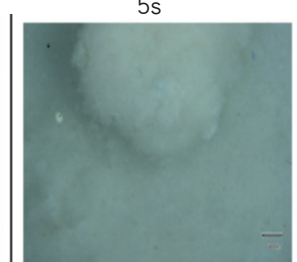

20 s

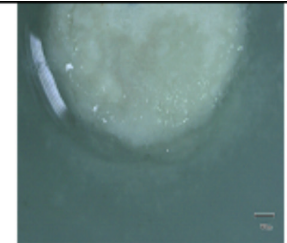

$10 \mathrm{~s}$

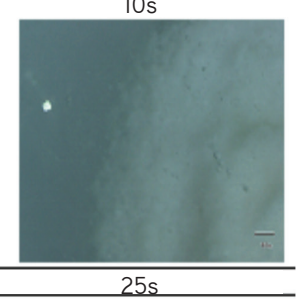

Figure 1. Stages of tablet disintegration, showing swelling and erosion of a tablet of formulation $\mathrm{F} 12$ at $0 \mathrm{~s}, 5 \mathrm{~s}, 10 \mathrm{~s}, 15 \mathrm{~s}, 20 \mathrm{~s}$, and $25 \mathrm{~s}$

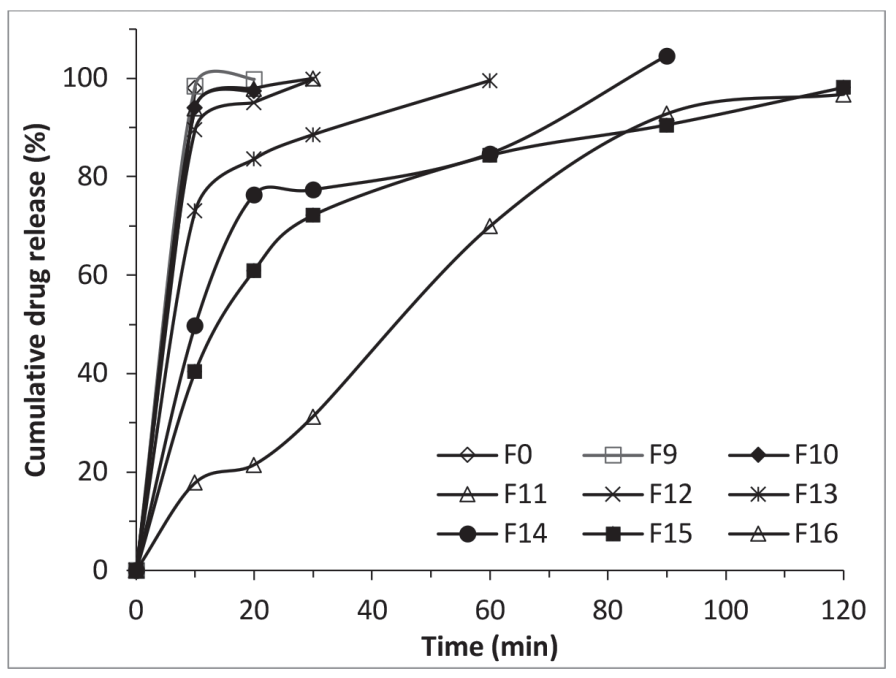

Figure 2. Dissolution profiles of orally disintegrating tablet formulations (F0 and F9-F16) having no Soluplus ${ }^{\circledR}$ or containing different concentrations of Soluplus ${ }^{\circledast}$ as release modifier

$\sim 75 \%$ from $\mathrm{F} 13, \sim 50 \%$ from $\mathrm{F} 14, \sim 40 \%$ from $\mathrm{F} 15$, and $~ 20 \%$ from F16. This trend remained similar after $30 \mathrm{~min}$, where the drug release was almost complete from formulations F10-F12, while F13 showed $~ 90 \%$, F14 $80 \%$, F15 70\%, and F16 30\% drug release. The results indicate that drug release was sustained by the incorporation of Soluplus ${ }^{\circledR}$ in ODTs and increasing the concentration of Soluplus ${ }^{\circledR}$ in the formulations from F9 (containing $5 \% \mathrm{w} / \mathrm{w}$ ) to $\mathrm{F} 16$ (50\% w/w with drug) enhanced the release-modifying effect of this copolymer. Statistical analysis showed a significant difference in drug release $(p<0.05)$ from all nine formulations. This indicated the significant role of Soluplus ${ }^{\circledR}$ in drug release.

This shows that Soluplus ${ }^{\circledR}$ has the ability to retard the drug release of naproxen sodium, a water-soluble drug. This effect of Soluplus ${ }^{\circledast}$ has been shown in some previous studies. ${ }^{21}$ In order to find the pattern of drug release from the tablet formulations, the release data were subjected to different release models. It was shown from the results that the Korsmeyer-Peppas model best fitted with the release profile with $R^{2}$ values 0.971 . The value of release coefficient " $n$ " was 0.748 , i.e. $>0.5$, indicating nonFickian or anomalous release from the tablet formulations. ${ }^{22}$

\section{CONCLUSION}

Orally disintegrating sustained release tablets of naproxen sodium, a water-soluble drug, were successfully prepared using an optimum concentration of croscarmellose sodium as disintegrant and Soluplus ${ }^{\circledR}$ as release modifier. The study highlighted the drug release modifying role of Soluplus ${ }^{\circledR}$ for the first time from tablet formulations.

\section{ACKNOWLEDGEMENTS}

The authors would like to thank the University of the Punjab, Lahore, Pakistan, for funding this project.

Conflicts of interest: No conflict of interest was declared by the authors. The authors alone are responsible for the content and writing of the paper.

\section{REFERENCES}

1. Shojaei, $\mathrm{AH}$. Buccal mucosa as a route for systemic drug delivery: a review. J Pharm Pharm Sci. 1998;1:15-30.

2. Abdelbary G, Prinderre P, Eouani C, Joachim J, Reynier JP, Piccerelle P. The preparation of orally disintegrating tablets using a hydrophilic waxy binder Int. J Pharm. 2004:278:423-433.

3. Hirani JJ, Rathod DA, Vadalia KR. Orally disintegrating tablets: a review trop. J Pharm Res. 2009;8:61-172.

4. Mahal RK, Dr. Samein LH, Shehab M. Formulation and in-vitro evaluation of orodispersible tablet. Int J Pharm Sci Res. 2015;4:689-696.

5. Sharma D, Kumar D, Singh M, Singh G, Rathore M. Fast disintegrating tablets: a new era in novel drug delivery system and new market opportunities. JDDT. 2012;1:74-86.

6. Reddy KR, Mutalik S, Reddy S. Once-daily sustained-release matrix tablets of nicorandil: formulation and in vitro evaluation. AAPS Pharm Sci Tech. 2003;4:480-488.

7. Tiwari SB, Murthy TK, Pai MR, Mehta PR, Chowdary PB. Controlled release formulation of tramadol hydrochloride using hydrophilic and hydrophobic matrix system. AAPS Pharm Sci Tech. 2003;4:18-23.

8. Sagar N, Goswami L, Kothiyal P. Orally disintegrating tablets: a review. Int J Apl Res. 2012;3:1222-1228.

9. Chang RK, Xiaodi G, Burnside BA, Couch RA. Fast-dissolving tablets. Pharm tech. 2000;24:52-58.

10. Fini A, Bergamante V, Ceschel GC, Ronchi C, de Moraes CAF. Fast dispersible/slow releasing ibuprofen tablets. Eur J Pharm Biopharm. 2008;69:335-341.

11. Wei $Q$, Yang $F$, Luan $L$. Preparation and in vitro/in vivo evaluation of a Ketoprofen orally disintegrating/sustained release tablet. Drug Dev Ind Pharm. 2013;39:928-934.

12. Amaral MH, Lobo JS, Ferreira D. Effect of hydroxypropyl methylcellulose and hydrogenated castor oil on naproxen release from sustained-release tablets. AAPS Pharm Sci Tech. 2001;2:14-21.

13. Badgujar B, Mundada AS. The technologies used for developing orally disintegrating tablets: a review. Acta Pharm. 2011;61:117-139. 
14. Setty CM, Prasad DVK, Gupta VRM, Sa B. Development of fast dispersible aceclofenac tablets: effect of functionality of superdisintegrants. Ind. J Pharm Sci. 2008;70:180

15. Shah RB, Tawakkul MA, Khan MA. Comparative evaluation of flow for pharmaceutical powders and granules. AAPS Pharm Sci Tech. 2008;9:250-258.

16. Elkhodairy KA, Hassan MA, Afifi SA. Formulation and optimization of orodispersible tablets of flutamide. Saudi Pharma J. 2014;22:53-61.

17. Siddiqui MN, Garg G, Sharma PK. Fast dissolving tablets: preparation, characterization and evaluation: an overview. IJPSRR. 2010;4:87-96.

18. Gohel MC, Parikh RK, Brahmbhatt BK, Shah AR. Preparation and assessment of novel coprocessed superdisintegrant consisting of crospovidone and sodium starch glycolate: a technical note. AAPS Pharm Sci Tech. 2007;8:E63-E69.
19. Djuric D. Solubility enhancement with BASF pharma polymers: Solubilizer compendium. BASF SE Pharma Ingredients \& Services, Germany: 2011;67-72.

20. Khairnar DA, Anantwar SP, Chaudhari CS, Shelke PA. Superdisintegrants: an emerging paradigm in orodispersible tablets. Int $\mathrm{J}$ Biopharm. 2014:5:119-128.

21. Naelapää K, Boetker JP, Müllertz A, Rades T, Rantanen J, Bar-Shalom D. Soluplus ${ }^{\circledast}$ for modifying the release of highly water soluble APIs. AAPS Annual meeting and exposition, Chicago, USA 2012.

22. Ford JL, Rubinstein MH, McCaul F, Hogan JE, Edgar PJ. Importance of drug type, tablet shape and added diluents on drug release kinetics from hydroxypropylmethylcellulose matrix tablets. Int J Pharm. 1987;40:223234. 